\title{
Modeling of Tests of Primary Water Stress Corrosion Cracking of Alloy 182 of Pressurized Water Reactor According to EPRI and USNRC Recommendations
}

\author{
Omar Fernandes Aly ${ }^{1, *}$, Miguel Mattar Neto ${ }^{1}$, Mônica Maria de Abreu Mendonça \\ Schvartzman ${ }^{2}$ and Luciana Iglésias Lourenço Lima ${ }^{3}$
}

${ }^{1}$ Nuclear Engineering Center, IPEN/CNEN-USP, São Paulo, Brazil

${ }^{2}$ CDTN/CNEN-UFMG, Belo Horizonte, Brazil

${ }^{3}$ Vallourec Research, Belo Horizonte, Brazil

\begin{abstract}
One of the main degradation mechanisms which cause risks to safety and reliability of pressurized water nuclear reactors is the primary water stress corrosion cracking (PWSCC) in nickel alloys, such as Alloy 600 (75Ni-15Cr$9 \mathrm{Fe})$, and its weld metal Alloy $182(67 \mathrm{Ni}-15 \mathrm{Cr}-8 \mathrm{Fe})$. It can appear at several reactor nozzles dissimilarly welded with Alloys 182/82 between steel ASTM A-508 G3 and stainless steel AISI316L, among others. The hydrogen which is dissolved to primary water to prevent radiolysis, can also have influence on the stress corrosion cracking behavior. In this article one departs from a study of Lima based in experimental data obtained from CDTN-Brazilian Nuclear Technology Development Center, in slow strain rate test (SSRT). It was prepared and used for tests a weld in laboratory, similar to dissimilar weld in pressurizer relief nozzles, operating at Brazilian NPP Angra 1. It was simulated for tests, primary water at $325^{\circ} \mathrm{C}$ and $12.5 \mathrm{MPa}$ containing levels of dissolved hydrogen: $2,10,25$, and $50 \mathrm{~cm}^{3} \mathrm{STP} \mathrm{H}_{2} / \mathrm{kgH}_{2} \mathrm{O}$. The objective of this article is to propose an adequate modeling based on these experimental results, for PWSCC crack growth rate according to the levels of dissolved hydrogen, based on EPRI-MRP-263 NP. Furthermore, it has been estimated the stress intensity factor applied for these tests: according with these, some another models described on EPRI-MRP-115, and an USNRC Technical Report, have been tested. According to this study, CDTN tests are adequate for modeling comparisons within EPRI and USNRC models.
\end{abstract}

Keywords: Hydrogen Effect, Modeling, Pressurized Water Stress Corrosion Cracking, Slow Strain Rate Tests, Weld Nickel Alloys 82/182.

\section{INTRODUCTION}

The PWSCC is a very complex degradation mode in Nuclear Pressurized Water Reactor (PWR) 's thickwalled components of nickel alloys - such as Alloy 600 and its weld metals (Alloy 182 and Alloy 82). It has been identified as an important mode affecting the safety and reliability of this type of plant operation. A constant effort has been done to develop and identify technologies to mitigate this damage mechanism. Until now, the main ones are hydrogen optimization and zinc injection, during PWR plant operations. The zinc injection is used to delay the PWSCC initiation due to its incorporation in spinel oxide films, thus enhancing their stability [1].

The hydrogen injection on primary water is normally applied to prevent radiolysis. The hydrogen optimization which consists in different hydrogen injection levels in primary water of the operating unity has been demonstrated to strongly mitigate the

*Address correspondence to this author at the Energy and Nuclear Research Institute- IPEN/CNEN-USP, Nuclear Engineering Center, Av. Lineu Prestes 2242- São Paulo University Campus, 05508-000 São Paulo-SP, Brazil; Tel: 55(11) 3133-9404; Fax: 55(11) 3133-9423;

E-mail: ofaly1@gmail.com, ofaly@ipen.br
PWSCC growth rate, mainly in Alloy 182 and Alloy 82 weld metals. With respect to the PWSCC initiation time, most of available data did not show a conclusive effect on this, mainly due to the high degree of scatter. Also, the hydrogen increase above current operational levels did not have an enhancement effect on PWSCC initiation time [2]. Also, according to these authors, the best for this case is zinc addition, which has been demonstrated strong mitigation of the initiation of PWSCC in Alloy 600: further, the zinc addition is an additional way of decreasing occupational radiation exposure of plant staff, according to Nordmann ${ }^{(1)}$.

It has been departed from a study of Lima [3] which investigates the influence of dissolved hydrogen contents on the susceptibility to PWSCC of Alloy 182 , used as weld metal in a dissimilar weld between the steel ASTM A-508 G3 and stainless steel AISI 316L, similar to the weld which exists in a pressurizer nozzle of Angra \# 1 nuclear power plant: it was evaluated. In this study was used a simulated PWR primary coolant water chemistry at $325^{\circ} \mathrm{C}$ and pressure of $12.5 \mathrm{MPa}$ with different levels of dissolved hydrogen: 2, 10, 25, $50 \mathrm{~cm}^{3} \mathrm{H} 2 / \mathrm{kg} \mathrm{H}_{2} \mathrm{O}$ at standard temperature and pressure (STP). Slow strain rate test (SSRT) was used to evaluate the Alloy 182 PWSCC susceptibility. Open 
circuit potential was measured in different hydrogen concentrations to evaluate their effect in the material electrochemical corrosion: the main study results indicated that Alloy 182 is less susceptible to PWSCC at $50 \mathrm{~cm}^{3} \mathrm{H}_{2}(\mathrm{STP}) / \mathrm{kg} \mathrm{H} \mathrm{H}_{2} \mathrm{O}$ at $325^{\circ} \mathrm{C}$, and showed the positive effect in to keep hydrogen concentration in a high level in the PWR primary coolant water.

The objective of this article is to study and to discuss an adequate modeling based on the experimental results from Lima 's study [3] for PWSCC growth rate according to the levels of dissolved hydrogen. It has been used from Section 7 of EPRIMRP 263 NP, a numerical model describing the effect of hydrogen on PWSCC growth rate which takes the form of a Gaussian distribution centered at the $\mathrm{Ni} / \mathrm{NiO}$ transition. This model is function of the difference in electrochemical potential $(\triangle \mathrm{ECP})$ between the $\mathrm{Ni} / \mathrm{NiO}$ transition and the test condition. Typical fitted parameters are the peak width and the peak to baseline ratio [2]. The SSRT did not include the stress intensity variation $(\Delta \mathrm{K})$, then it would be possible according to the CDTN data, to apply only the referred model from MRP-263 NP, now appealed "hydrogen $\triangle \mathrm{ECP}$ submodel". But it has been estimated the stress intensity factor applied for these tests: according to this, one has been possible to do some comparison with another technical recommendations from EPRI [4] and USNRC [5].

\subsection{The Hydrogen $\triangle E C P$ Submodel}

The Sections 6 and 7 of EPRI-MRP 263 NP [2] treat about respectively mitigation of PWSCC initiation through elevated hydrogen content, and mitigation of PWSCC propagation through elevated hydrogen content. The conclusion of section 6 is based only in the Alloy 600 case, and is that according to the available data did not exist a hydrogen effect on PWSCC initiation in this nickel alloy: the case of Alloy 182 was not considered. But in Section 7, it was studied the hydrogen effect on Alloy 600, and Alloy 182 (here the interest case). The considered model described the effect of hydrogen on PWSCC propagation in the form of a Gaussian distribution centered at the $\mathrm{Ni} / \mathrm{NiO}$ transition. This model is function of the difference in ECP between the $\mathrm{Ni} / \mathrm{NiO}$ transition and the test condition (Equation (1)). Typical fitted parameters are the peak width (c) and the peak to baseline ratio $(P)$. The concentration of hydrogen corresponding to the potential at the $\mathrm{Ni} / \mathrm{NiO}$ transition is temperature dependent (Equations (2) and (3)).

$$
\begin{aligned}
& C G R=C G R_{\max }\left[\left[\frac{1}{P}+\frac{(P-1)}{P} \exp \left(\left(-0.5\left(\frac{\Delta E C P_{N i / N i O}}{c}\right)^{2}\right)\right]\right.\right. \\
& \Delta E C P_{\text {Ni/NiO }}=29.58\left(\frac{T_{r e f}+273.15}{298.15}\right) \log \left(\frac{\left[H_{2}\right]}{\left[H_{2}\right]_{N i / N i O}}\right) \\
& {\left[H_{2}\right]_{N i / N i O}=10^{(0.0111 \text { ref }-2.59)}}
\end{aligned}
$$

where: $C G R$ is the crack growth rate, $C G R_{\max }$ is the maximum CGR at the $\mathrm{Ni} / \mathrm{NiO}$ transition, $P$ is the ratio of the maximum to minimum expected CGR, $c$ is the peak width, $\triangle E C P_{\mathrm{Ni} / \mathrm{NiO}}$ is the ECP difference from the $\mathrm{Ni} / \mathrm{NiO}$ transition, $T_{\text {ref }}$ is the reference temperature (in Celsius degrees) in test condition, $\left[H_{2}\right]$ is the hydrogen concentration on environment, $\left[H_{2}\right]_{\mathrm{Ni} / \mathrm{NiO}}$ is the $\left[H_{2}\right]$ on the $\mathrm{Ni} / \mathrm{NiO}$ transition.

On the Table 7-2 of EPRI-MRP 263 NP [2] are presented model parameters for Alloy 182 data sets from various authors, as well as its average and standard deviation values. On the Figures 7-7 to 7-10 of EPRI-MRP $263 \mathrm{NP}$ are presented graphics CGR vs. $\triangle \mathrm{ECP}_{\mathrm{Ni} / \mathrm{NiO}}$ departing from raw data for Alloy 182 from researchers Andresen and Toloczko [2].

\subsection{The MRP-115 Model}

The MRP-115 is a technical recommendation which has been done with the objective for a qualified equation for CGR to evaluate defects found by inservice inspection. It is applied to wrought Alloy 600 base material, and also to its weld metals, the Alloys 182, 82, and 132. The nuclear components included the primary circuit welds with high residual stresses and in some J-groove welds attaching control rod drive mechanism (CRDM) and bottom mounted instrumentation (BMI) nozzles to the reactor upper head. The weld metals are by definition "as-cast" structures and, consequently are much more inhomogeneous than wrought materials. This characteristic generates data scattering due to the variations on the microscopic scale of weld metals. So, the simple multiplication factor approach is not suitable for extensive use, and necessitated the development of a more sophisticated methodology. The main model which would be applicable to the CDTN data is given by equation (4) [4].

$$
C G R=\exp \left[-\frac{Q}{R}\left(\frac{1}{T}-\frac{1}{T_{\text {ref }}}\right)\right] \alpha f_{\text {alloy }} f_{\text {orient }} K^{\beta}
$$


where: $C G R$ is the crack growth rate at temperature $T$, $Q$ is the thermal activation energy for crack growth, $R$ is the universal gas constant, $T$ is the absolute operating temperature at location of crack in the test condition, $T_{\text {ref }}$ is the absolute reference temperature at location of crack in test condition, $\alpha$ is a power law constant, $f_{\text {alloy }}$ is a constant value depending on material, $f_{\text {orient }}$ is a constant value depending on the dendrites solidification direction in the weld, $K$ is the crack tip stress intensity factor, $\beta$ is a proper exponent.

\subsection{The USNRC Model}

The USNRC model is extracted from a report which has been done with the objective to study the CGR results and related metallography for field and laboratory specimens of Alloy 600 and its weld alloys tested in PWR environments. This report also has been presented CGR results for a shielded-metal-arc weld of Alloy 182 in a simulated PWR environment as a function of temperature between $290^{\circ} \mathrm{C}$ and $350^{\circ} \mathrm{C}$. These data were used to determine the activation energy for crack growth in Alloy 182 welds. The tests were done by measuring the changes in the CGR as the temperatures were varied during the tests. The difference in electrochemical potential between the specimen and the $\mathrm{Ni} / \mathrm{NiO}$ line was kept constant at each temperature by adjusting the hydrogen overpressure. The model has been extracted from the normalization for the nickel weld data to study the use of different activation energies, and is showed in equation (5) [5].

$C G R_{\text {Ni-weld }}=1.1 \times 10^{-12} \exp \left[-\frac{Q}{R}\left(\frac{1}{T}-\frac{1}{T_{\text {ref }}}\right)\right] K^{1.6}$ where: $C G R_{N i \text {-weld }}$ is the nickel-weld crack growth rate at temperature $T$, and the other symbols are the same as in equation (4). Note also that equation (5) is basically the same equation (4).

\section{MATERIAL AND METHODS}

The original study of Lima [3] comprised: a) Dissimilar material weldment from Angra reactor \#1 reproduction in CDTN mechanical workshop, according to the ASME Boiler and Pressure Vessel Code Section IX, Welding and Brazing Qualification, and the AWS specifications to the welding electrodes: this weldment has been done between two plates of AISI 316L and ASTM A-508 filled with Alloy 182 in a chamfer previously buttered with Alloy 82 ; b) Chemicalmechanical-structural characterization of weld and related materials, according to ASTM E4, and ASTM E8; c) Evaluation of the corrosion potential of the Alloy 182 at high-temperature; d) Obtaining and characterization of oxide passive film formed in Alloy 182 on primary water environment at hightemperature; e) SSRT with Alloy 182 specimens at different levels of dissolved hydrogen in the test environment, according to ASTM G 49, and ASTM G 129.

The materials are basically done at Table $\mathbf{1}$, divided in base (two upper rows) and weld filler metals [3].

The basic mechanical properties of the main studied material, the Alloy 182 are given at Table 2 [3].

The quantification of the PWSCC brittle fracture surface and its depth was obtained departing from the scanning electron microscope (SEM) micro fractographies of the tested specimens: the images

Table 1: Chemical Composition of the Base and Filler Metals (wt\%) [3]

\begin{tabular}{|c|c|c|c|c|c|c|c|c|c|c|c|}
\hline & $\mathbf{C}$ & $\mathbf{M n}$ & $\mathbf{S i}$ & $\mathbf{P}$ & $\mathbf{S}$ & $\mathbf{C r}$ & $\mathbf{N i}$ & $\mathbf{N b}$ & $\mathbf{T i}$ & $\mathbf{M o}$ & $\mathbf{F e}$ \\
\hline \hline AISI 316L & 0.023 & 1.46 & 0.475 & 0.021 & 0.003 & 16.7 & 9.8 & 0.02 & 0.03 & 2.10 & Bal. \\
\hline ASTM A508 & 0.21 & 1.34 & 0.227 & 0.005 & 0.003 & 0.09 & 0.68 & 0.002 & 0.001 & 0.51 & Bal. \\
\hline Alloy 182 & 0.05 & 6.16 & 0.341 & 0.01 & 0.009 & 14.3 & 70.3 & 2.07 & 0.049 & 0.24 & Bal. \\
\hline Alloy 82 & 0.04 & 3.4 & 0.141 & 0.012 & 0.005 & 18.9 & 73 & 2.47 & 0.25 & 0.16 & Bal. \\
\hline
\end{tabular}

Table 2: Basic Mechanical Properties of the Filler Metal Alloy 182 [3]

\begin{tabular}{|c|c|c|c|c|}
\hline & Temperature $\left({ }^{\circ} \mathbf{C}\right)$ & $\begin{array}{c}\text { Yield Strength } \\
\text { YS }_{0.2 \%}(\mathbf{M P a})\end{array}$ & $\begin{array}{c}\text { Ultimate Tensile } \\
\text { Strength (MPa) }\end{array}$ & $\begin{array}{c}\text { Percentual Elongation } \\
(\%)\end{array}$ \\
\hline \hline Alloy 182 & 25 & $400 \pm 40$ & $620 \pm 12$ & $44 \pm 3$ \\
\hline Alloy 182 & 325 & $328 \pm 28$ & $500 \pm 30$ & $47 \pm 3$ \\
\hline
\end{tabular}


were processed by a Quantikov equipment, and the evaluation of the CGR according to a method developed by Totsuka et al., quoted in the references of Lima [3]: see also pp.63-64 from this study for more information.

The main results of Lima study, concerning the value to modeling data, according to EPRI-MRP 263 NP [2], were the Tables 3 and $\mathbf{4}$ below reproduced from this: these Tables correspond graphically to the originals Figure 4.38 (page 100), and Figure 4.37 (page 99) from the study of Lima [3]. In Figure 1, it is reproduced the original Figure 4.38.

In the Table 3, $E_{\text {cor }}$ represents the corrosion potential, and $\triangle \mathrm{ECP}_{\mathrm{Ni} / \mathrm{NiO}}$ is the electrochemical potential (ECP) difference from that of the $\mathrm{Ni} / \mathrm{NiO}$ transition: this is a very important parameter, because changes in the hydrogen concentration in primary water enforce that the corrosion potential reaches the $\mathrm{Ni} / \mathrm{NiO}$ transition line in the Potential versus $\mathrm{pH}$ equilibrium diagram between $\mathrm{Ni}$ and water, and have a strong influence in the stress corrosion cracking

Table 3: Resulting Values of $\mathrm{E}_{\mathrm{cor}}$ and $\triangle \mathrm{ECP}_{\mathrm{Ni} / \mathrm{Nio}}$ to Alloy 182 in PWR Primary Water at $325^{\circ} \mathrm{C}$ [3]

\begin{tabular}{|c|c|c|}
\hline Test Environment & $\mathbf{E}_{\text {cor }}\left(\mathbf{m V}_{\mathrm{SHE}}\right)$ & $\Delta \mathbf{E C P}_{\text {Ni } / \mathrm{NiO}}\left(\mathbf{m V}_{\text {SHE }}\right)$ \\
\hline \hline $2 \mathrm{~cm}^{3} \mathrm{H}_{2}(\mathrm{STP}) / \mathrm{kg} \mathrm{H} \mathrm{O}$ & -717 & -18 \\
\hline $10 \mathrm{~cm}^{3} \mathrm{H}_{2}(\mathrm{STP}) / \mathrm{kg} \mathrm{H} \mathrm{O}$ & -735 & 0 \\
\hline $25 \mathrm{~cm}^{3} \mathrm{H}_{2}(\mathrm{STP}) / \mathrm{kg} \mathrm{H} \mathrm{O}$ & -756 & 21 \\
\hline $50 \mathrm{~cm}^{3} \mathrm{H}_{2}(\mathrm{STP}) / \mathrm{kg} \mathrm{H} \mathrm{H}_{2} \mathrm{O}$ & -776 & 41 \\
\hline
\end{tabular}

Table 4: Crack Growth Rate (CGR) to Alloy 182 in PWR Primary Water at $325^{\circ} \mathrm{C}[3]$

\begin{tabular}{|c|c|c|}
\hline Dissolved Hydrogen & Crack Depth (mm) & $\mathbf{A}_{\text {IGscc }}(\%)$ \\
\hline $2 \mathrm{~cm}^{3} \mathrm{H}_{2}(\mathrm{STP}) / \mathrm{kg} \mathrm{H}_{2} \mathrm{O}$ & 0.836 & 14 \\
\hline $10 \mathrm{~cm}^{3} \mathrm{H}_{2}(\mathrm{STP}) / \mathrm{kg} \mathrm{H} \mathrm{H}_{2} \mathrm{O}$ & 1.3 & 33 \\
\hline $15 \mathrm{~cm}^{3} \mathrm{H}_{2}(\mathrm{STP}) / \mathrm{kg} \mathrm{H} \mathrm{H}_{2} \mathrm{O}$ & 1.18 & 25 \\
\hline $25 \mathrm{~cm}^{3} \mathrm{H}_{2}(\mathrm{STP}) / \mathrm{kg} \mathrm{H} \mathrm{H}_{2} \mathrm{O}$ & 1.04 & 20 \\
\hline $50 \mathrm{~cm}^{3} \mathrm{H}_{2}(\mathrm{STP}) / \mathrm{kg} \mathrm{H} \mathrm{H}_{2} \mathrm{O}$ & 0.573 & 6 \\
\hline Dissolved Hydrogen & Time to failure $t_{f}(h)$ & $\mathrm{CGR}(\mathrm{mm} / \mathrm{s})$ \\
\hline $2 \mathrm{~cm}^{3} \mathrm{H}_{2}(\mathrm{STP}) / \mathrm{kg} \mathrm{H}_{2} \mathrm{O}$ & 324 & $1.3 \times 10^{-7}$ \\
\hline $10 \mathrm{~cm}^{3} \mathrm{H}_{2}(\mathrm{STP}) / \mathrm{kg} \mathrm{H} \mathrm{H}_{2} \mathrm{O}$ & 216 & $5.0 \times 10^{-7}$ \\
\hline $15 \mathrm{~cm}^{3} \mathrm{H}_{2}(\mathrm{STP}) / \mathrm{kg} \mathrm{H} \mathrm{H}_{2} \mathrm{O}$ & 273 & $2.9 \times 10^{-7}$ \\
\hline $25 \mathrm{~cm}^{3} \mathrm{H}_{2}(\mathrm{STP}) / \mathrm{kg} \mathrm{H} \mathrm{H}_{2} \mathrm{O}$ & 278 & $2.1 \times 10^{-7}$ \\
\hline $50 \mathrm{~cm}^{3} \mathrm{H}_{2}(\mathrm{STP}) / \mathrm{kg} \mathrm{H} \mathrm{O}$ & 384 & $2.9 \times 10^{-8}$ \\
\hline
\end{tabular}

behavior. In the Table $\mathbf{4}, A_{1 G s c c}$ is the brittle fracture surface area ratio to the total fracture surface area, remembering that IGSCC is the intergranular stress corrosion cracking, the predominant type of PWSCC in this case.

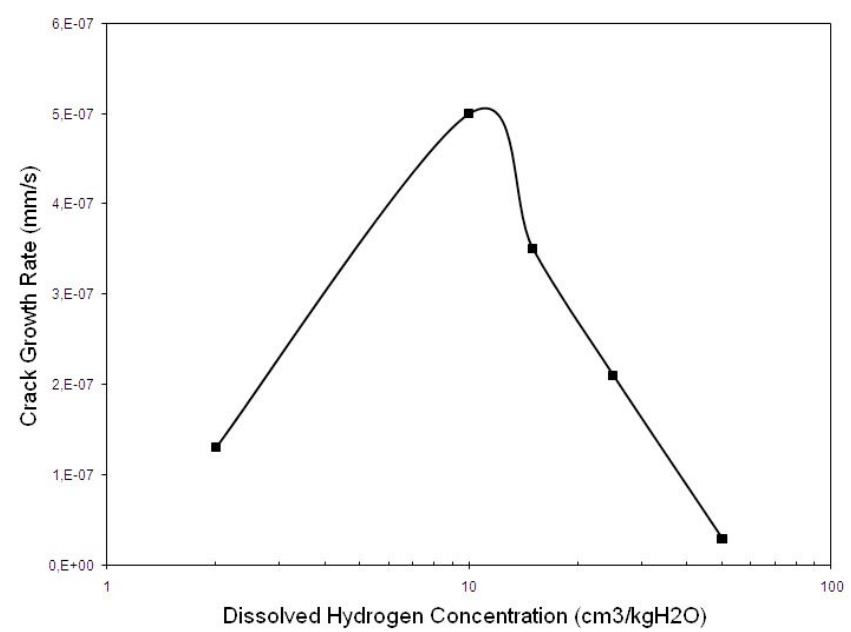

Figure 1: Experimental result for Alloy 182 SSR tested at $325^{\circ} \mathrm{C}$ in primary water with strain rate $3.10^{-7} \mathrm{~s}^{-1}$, from Lima [3].

\section{RESULTS}

\subsection{The Hydrogen $\triangle E C P$ Submodel}

The obtained result applying experimental CDTN data results on equations (1) to (3) is done by simple algebraic substituition, and the main model equation is a normal/gaussian distribution according to equation (6).

$C G R=1.7\left[\left[\frac{1}{17.2}+\frac{(17.2-1)}{17.2} \exp \left(\left(-0.5\left(\frac{\Delta E C P_{\text {NiNiO }}}{15.2}\right)^{2}\right)\right]\right.\right.$

(mils / day)

\subsection{The MRP-115 Model}

The SSRT of CDTN were not performed with controlled stress intensity factor $(\mathrm{K})$ variation, but it 's possible to estimate a K-value where probably the tests were done. To estimate it, one is departed from equation (7) which represents the $\mathrm{K}$ in mode I to a fully circumferential crack in a bar [6] (that is a simplification related to the actual case, because the axial crack depth is not completely constant).

$$
K_{I}=(Y \sigma) \sqrt{\pi a}
$$


where: $\sigma=$ stress, $a=$ crack depth, $Y=$ factor which represents the total contribution of the primary and secondary stresses.

The considered values to be used in Equation (7) were: $\sigma=440 \mathrm{MPa}, \mathrm{a}=1.04 \times 10^{-3} \mathrm{~m}$ - both values corresponding to the case where the hydrogen concentration is equal to $25 \mathrm{~cm}^{3} \mathrm{H}_{2} / \mathrm{kg} \mathrm{H} \mathrm{H}_{2} \mathrm{O}$ (see also Figure 4-24 from Lima, showing the stress versus strain curves obtained on SSRT at CDTN and the stress is the average stress of the SSRT applied to the specimen at $\left.325^{\circ} \mathrm{C}\right), Y \approx 1$, considering contribution of primary stress far greater than the contribution of secondary stress. Then, the found estimated K-value is $25.15 \mathrm{MPa} \sqrt{ } \mathrm{m}$.

So, it can be considered the point (CGR, K) obtained in CDTN test at $25 \mathrm{~cm}^{3} \mathrm{H}_{2} / \mathrm{kg} \mathrm{H}_{2} \mathrm{O}$ and $25^{\circ} \mathrm{C}$ (see also Table 4) equal to $\left(2.1 \times 10^{-10} \mathrm{~m} / \mathrm{s} ; 25 \mathrm{MPa}\right.$ $\sqrt{\mathrm{m}}$ ). This test point can be plotted on the disposition curve of the MRP-115 [4] according to Figure 2.

\subsection{The USNRC Model}

The resulting modeling is almost immediate when it has been substituted the K-value on equation (5), remembering that $T=T_{\text {ref }}=325^{\circ} \mathrm{C}$ :

$C G R_{\text {Ni-weld }}=1.1 \times 10^{-12} \exp (0)(25.15)^{1.6}=1.9 \times 10^{-10}$ $\mathrm{m} / \mathrm{s}$.

From Table 4, it has found CGR for CDTN test at reference temperature equal to $2.1 \times 10^{-10} \mathrm{~m} / \mathrm{s}$.

\section{DISCUSSION}

\subsection{The Hydrogen $\triangle E C P$ Submodel}

Based on equation (6), one has been plotted in Figure 3, the corresponding normal curve (in blue), and also plotted the red curve from Andresen raw data [2], as the closer in the MRP-263 NP relating to the CDTN data.

It can be noted that the peak/baseline ratio $(P)$ in the CDTN case is greater than in the Andresen raw data case. Probably this is due to the different test methodologies used: CDTN used an accelerated test, the SSRT; despite in the Andresen raw data case the used tests were not identified (that is because the Andresen' $s$ references were deleted from the document, as "proprietary information"), normally this researcher uses the constant load test. But the "hydrogen $\triangle \mathrm{ECP}$ submodel" is applicable in both cases, because the Gaussian regression is valid to them. The differences are in the parameters $(P, C)$ as showed in equation (1). Maybe could be interesting to include in the MRP-263 NP data sets of SSRT to be compared.

\subsection{The MRP-115 Model}

Although the CDTN data set was not performed considering K-variation, and the data sets in the MRP115 [2] did not consider the hydrogen variation, it is possible to estimate a $\mathrm{K}$ value to the CDTN tests, and considering only one level of dissolved hydrogen $(25$

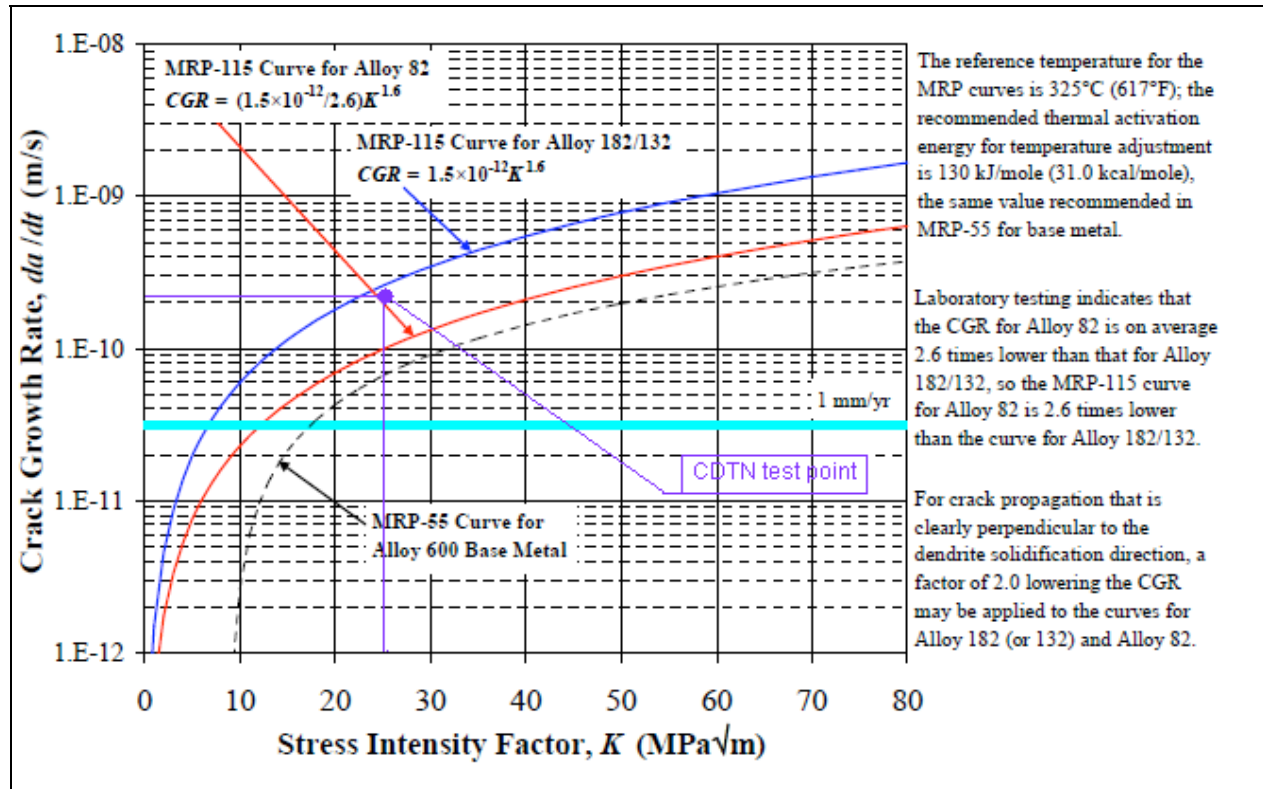

Figure 2: Plotting modeling to the CDTN test point (in purple) over the MRP-115 disposition curves to the Alloys $182 / 132$ and 82: the original graphic is the Figure 4-6 from reference [4]. 


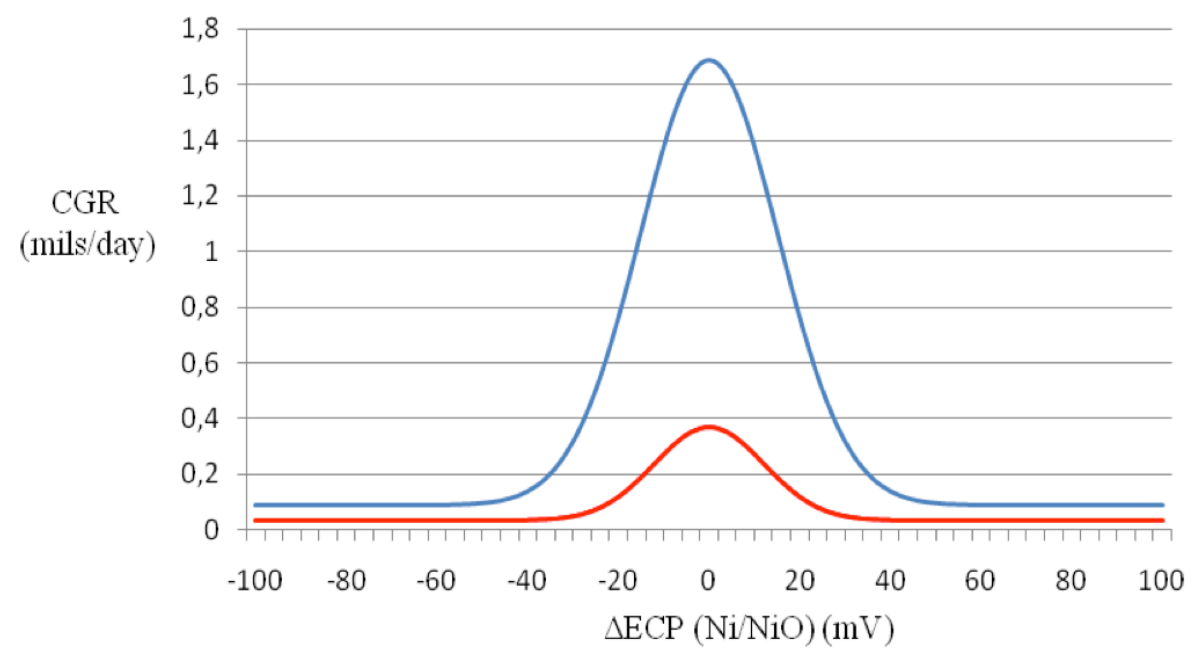

Figure 3: Equation (6) modeling fit to Alloy 182 CDTN data (blue) [3] compared to raw data from Andresen (red) [2]. Plotted through Microsoft Excel 2007.

$\mathrm{cm}^{3} \mathrm{H}_{2}(\mathrm{STP}) / \mathrm{kg} \mathrm{H}_{2} \mathrm{O}$ ) in the environment, to compare the obtained results. This result plotted in Figure 2 shows that the "CDTN test point" (in purple) at $325^{\circ} \mathrm{C}$ is close to the MRP-115 disposition curve (in blue) for Alloy $182 / 132$ at $325^{\circ} \mathrm{C}$. Naturally more tests with Kvariation should be performed at CDTN laboratories to confirm the MRP-115 disposition curve modeling tendency, but only one estimated result so close to this curve that allows to expect, in a complete data set according to CDTN methodology added with the Kvariation condition, an almost coincident regression according to MRP-115 and to CDTN.

\subsection{The USNRC Model}

The result of CDTN experimental CGR value compared to the correspondent modeling value according to the USNRC is about $9.5 \%$ higher than that. So, the modeling appears to be less conservative than the CDTN experimental methodology, and it seems to be easily explicable due to different test methodologies using in various data sets used to do the USNRC model.

\section{CONCLUSION}

This paper presented a modeling and modeling study of tests of primary water stress corrosion of Alloy 182, realized at CDTN installations and comprising the hydrogen $\triangle \mathrm{ECP}$ submodel, which relates the CGR with the dissolved hydrogen variation in the tested environment: the result showed a good qualitative adjustment, but different quantitative adjustment, due probably to different test methodologies used to obtain the data sets. Also it has been done a study considering a modeling comparison with the disposition modeling curve in the EPRI-MRP-115, and also in an USNRC Technical Report. Both results a good initial adjustment, but more tests with K-variation should be done at CDTN to produce complete regression curves according to these models. It should also include in the EPRI-MRP-263 NP more study concerning SSRT data sets.

\section{ACKNOWLEDGEMENTS}

ABM (Associação Brasileira de Metalurgia, Materiais e Mineração): this technical contribution has been originally published in the Proceedings of the $68^{\text {th }}$ ABM International Congress, July $30^{\text {th }}$ to August $2^{\text {nd }}$ 2013, held in Belo Horizonte - MG - Brazil edited by the Associação Brasileira de Metalurgia,Materiais e Mineração-ABM; Capes (Coordenação de Aperfeiçoamento de Pessoal de Nível Superior - Brazil) for this research fund, IPEN/CNEN-USP (Instituto de Pesquisas Energéticas e Nucleares/ Conselho Nacional de Energia Nuclear - Brazil), and CDTN/CNEN-UFMG (Centro de Desenvolvimento da Tecnologia Nuclear/ Conselho Nacional de Energia Nuclear - Brazil), for this research opportunity and infrastructure.

\section{REFERENCES}

[1] Nordmann F. PWR and BWR chemistry optimization. Nuc Eng Int 2011; 24-29. Avaliable from: http://www.neimagazine. com/features/featurepwr-and-bwr-chemistry-optimization/

[2] Marks C, Dumouchel M, Adler J. Materials Reliability Program: Technical Bases for the Chemical Mitigation of Primary Water Stress Corrosion Cracking in Pressurized Water Reactors (MRP-263 NP). EPRI, Palo Alto, CA, USA: 2012; 1025669 . 
[3] Lima LIL. Influence of concentration of hydrogen in stress corrosion susceptibility of welded joint with dissimilar metals in primary water environment of nuclear reactor (Influência da Concentração de Hidrogênio na Suscetibilidade à Corrosão Sob Tensão de Junta Soldada com Metais Dissimilares em Ambiente do Circuito Primário de Reator Nuclear). Thesis (Doctor) in Portuguese. UFMG: Belo Horizonte, Brasil, 2011; Avaliable from: UFMG Digital Library, http://hdl.handle.net/1843/BUOS-8NWH82

[4] White G, Gorman J, Nordmann N, Jones P, Kreider M. Materials Reliability Program: Crack Growth Rates for Evaluating Primary Stress Corrosion Cracking (PWSCC) of
Alloy 82, 182, and 132 Welds (MRP-115). EPRI, Palo Alto, CA, USA 2004; 1006696.

[5] Alexandreanu B, Chopra OK, Shack WJ. Crack Growth Rates and Metallographic Examinations of Alloy 600 and Alloy 82/182 from Field Components and Laboratory Materials Tested in PWR Environments. USNRC/ANL: Argonne, IL, USA 2008; (NUREG/CR-6964 and ANL-07/12)

[6] Fitnet MK7, Stress Intensity Factor Solutions [homepage on the internet] [cited 2012 Nov]. Avaliable from http://ocw.unican.es/ensenanzas-tecnicas/integridadestructural/otros-recursos-1/soluciones_fit_fitnet_pdf

Received on 27-05-2014

Accepted on 20-10-2014

Published on 08-12-2014

DOI: http://dx.doi.org/10.6000/1929-6002.2014.03.04.8

(C) 2014 Aly et al.; Licensee Lifescience Global.

This is an open access article licensed under the terms of the Creative Commons Attribution Non-Commercial License (http://creativecommons.org/licenses/by-nc/3.0/) which permits unrestricted, non-commercial use, distribution and reproduction in any medium, provided the work is properly cited. 